\title{
Fitopatolojide Nanoteknoloji
}

\section{Nanotechnology in Phytopathology}

\author{
Aydın ATAKAN ${ }^{1 *}$ iD, Hülya ÖZGÖNEN ÖZKAYA ${ }^{2}$ \\ ${ }^{1}$ Gaziantep Üniversitesi, Araban MYO, Bitki Koruma Programı, Gaziantep \\ ${ }^{2}$ Süleyman Demirel Üniversitesi, Ziraat Fakültesi, Bitki Koruma Bölümü, Isparta
}

To cite this article:

Atakan, A., Özgönen Özkaya, H., 2018. Fitopatolojide nanoteknoloji. Harran Tarim ve Gida Bilimleri Dergisi, 22(2): 296-303

\section{Address for Correspondence: Aydın ATAKAN \\ e-mail: \\ aydinatakan@gantep.edu.tr}

\section{Received Date:}

23.01.2017

Accepted Date:

08.02.2018

() Copyright 2018 by Harran University Faculty of Agriculture. Available on-line at www.dergipark.gov.tr/harranziraat

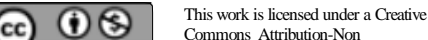
Commons Attribution-Non Commercial 4.0 Internation

\section{öz}

Son yıllarda farklı alanlarda kullanılan nanoteknoloji, fitopatolojik açıdan da yeni yaklaşımlar ortaya çıkarmıştır. Bitki hastalıklarıyla mücadelede kullanılan nanoteknolojik partiküller, ultra küçük boyutları ve farklı etki mekanizmalarına sahip olmalarıyla etkin bir kontrol sağlamaktadırlar. Bu amaçla altın, gümüş, çinko ve bakır vb. nanopartiküller yaygın olarak kullanılmaktadır. Ayrıca; nanofilm ve nanokaplama uygulamaları, akılı salım sistemlerinde uygulanabilirliği, nanopartiküllerin patojenlerin saptanmasında biyomarkör olarak kullanımı ve pestisit kalıntı analizlerinde nanosensör olarak kullanılabilirliği nanoteknoloji uygulamalarının diğer kullanım alanlarını oluşturmaktadır. Bitki hastalıklarıyla mücadele başarıyla kullanılabilen nanopestisitlerin üstün taşınma özelliği ve uzun süreli etkinliği toprak, su ve sıcak kanlılar üzerinde olumsuz etkilere yol açabileceği için kullanım öncesinde olumsuz yönleri de geniş çaplı araştırılmalıdır.

Anahtar Kelimeler: Nanoteknoloji, fitopatoloji, nanopestisit, hastalık kontrolü

\begin{abstract}
In recent years, nanotechnology, which is used in different fields, has brought new approaches in terms of phytopathology. Nanotechnological particles used in conrol of plant diseases provide effective control by having ultra-small dimensions and different mechanisms of action. For this purpose, nanoparticles such as gold, silver, zinc and copper are widely used. In addition, nanofilm and nanocomposing applications, applicability in intelligent release systems, use of nanoparticles as biomarkers in the detection of pathogens and their use as nanosensors in pesticide residue analysis constitute other uses of nanotechnology applications. The superior transportability and long-term efficacy of nanopesticides, which can be successfully used in combating plant diseases, can lead to adverse effects on soil, water and hot blood, Hence the adverse effect of nanoparticles should be investigated widely before use.
\end{abstract}

Key Words: Nanotechnology, phytopathology, nanofungicide, disease control

\section{Giriş}

Bitki patolojisi zaman zaman bilim ve teknoloji dalları tarafından etkilenmektedir. Daha önceleri bitki biyoteknolojisi tarafından etkilenen bitki patolojisi son zamanlarda da nanoteknolojinin etkisi altında kalmıştır (Banik ve Sharma, 2011). 21. yüzyılın teknoloji devrimi olarak kabul edilen nanoteknoloji tüm dünyada ve ülkemizde önce bilim çevrelerinde daha sonra da sanayi kuruluşlarında ön plana çıkmış ve yavaş yavaş tıptan tekstile, havacılık ve uzay araştırmalarından tarıma kadar birçok alanda kullanılabilir hale gelmiştir. Konu her ne kadar kimya ve fizik gibi temel bilimlerin çalışma alanı gibi görünse de çıktıları tarımı da olumlu yönde etkilemektedir 
(Gopal ve ark., 2011).

Nano kelimesi Yunanca kökenli olup "cüce" anlamı taşımaktadır. Bilimsel anlamda kullanıldığında ise herhangi bir fiziksel büyüklüğün bir milyarda biri anlamına gelmektedir (Tegart, 2003). Nanometre ise bir metrenin milyarda birine eşit bir uzunluk birimidir. İnsan saç telinin çapının yaklaşık 100.000 nanometre $(\mathrm{nm})$ olduğu düşünüldüğü zaman ne kadar küçük bir birimden bahsedildiği kolayca anlaşılabilmektedir. Bir başka deyişle, bir nanometre içine yan yana ancak 2-3 atom dizilebilir (Çıracı, 2005). Nanoteknoloji; fizik, kimya, biyoloji, tıp ve mühendislik alanlarını içine alan disiplinlerarası bir bilimdir ve $1-100$ nanometre ölçeğindeki fiziksel, kimyasal ve biyolojik yapıların anlaşılması, kontrol edilmesi ve atomsal seviyede değiştirilip fonksiyonel hale getirilmesi olarak tanımlanabilir (Singh, 2006).

Günümüzde birçok alanda nanoteknoloji kullanımını görmek mümkündür. Nanoteknolojinin kullanıldığı alanlar arasında; malzeme ve imalat sektörü, elektronik ve bilgisayar teknolojileri, havacılık ve uzay araştırmaları, tıp ve sağlık alanları, çevre ve enerji, ve de gıda endüstrisi yer almaktadır (Sharon ve ark., 2010). Son zamanlarda oldukça hızlı ilerleyen nanoteknoloji, tarım bilimlerinde de devrim niteliğinde gelişmeler ortaya çıkarmıştır. Makromateyallerin nano boyutlu (1-100 nm) partiküllere dönüşümü partiküllere yeni özellikler ve farklı davranış şekilleri kazandırmaktadır (Khan ve Rizvi, 2014). Makropartiküllere göre yüzey/hacim oranının çok daha yüksek olması nanopartiküllerin reaktifliğini ve biyokimyasal aktivitesini artırmaktadır (Dubchak ve ark., 2010). Bitkileri patojen saldırılarından korumak için toprak, tohum ya da yaprak gibi bitki kısımlarına, nanopartiküllerin doğrudan uygulanabilir olması en basit uygulama yöntemini oluşturmaktadır (Khan ve ark., 2014).

Geleneksel pestisitler, faydalı türlerin yok edilmesi, amaç dışı kullanımın zararlı boyutlara ulaşması, gıdalar üzerinde rezidü oluşumu, hastalık etmenleri ve zararlılarda direnç gelişimi ve zehirlenme etkileri ile kanser vb. gibi olası sağlık sorunlarına sebep olmaktadır.
Nanoteknolojik

yöntemlerle

üretilen

nanoformülasyonlar klasik formülasyonlarla karşılaştırıldığında çok daha az oranda aktif madde içeriğine sahip olması nedeniyle bu vb. sorunların üstesinden gelme yeteneğine sahiptirler (Vijayalakshmi ve ark., 2015). Ultraküçük boyutlara sahip olmasıyla bir çok alanda başarıyla kullanılabilen nanopartiküller, ne yazık ki sıcak kanlılar, çevre ve bitkiler üzerinde de bazı olumsuz etkilere yol açabilmektedir. nanopestisitler hava yoluyla taşınımları sırasında bitkilerin yaprak ve çiçek kısımlarında akümüle olarak stomaların tıkanmasına, stigma üzerinde polen çimlenmesini engelleyen bir tabaka oluşumuna ve vasküler dokulara girerek su, besin ve asimilasyon ürünlerinin taşınmasına olumsuz etkilerde bulunabilirler. İnsan ve hayvanlar tarafından teneffüs edildiğinde akciğerlerin derinliklerine kadar girebilmekte ve solunum üzerinde kötü etkiler yapabilmektedir. Nanopestisitlerin üstün taşınma özelliği, daha uzun kalıcılık sağlaması ve reaktifliğinin yüksek olması nedeniyle toprak ve su bünyelerinde yeni kirlilikler ortaya çıkabilmektedir (Khan ve Rizvi, 2014). Bu sebeple, nanoteknoloji tabanlı ürünlerin bitki koruma amaçlı geniş çapta kullanımından önce olumsuz etkilerinin olup olmadığı derinlemesine araştırımalıdır( Kamel ve Mousa 2015).

$\mathrm{Bu}$ derlemede, tarımda yeni bir yaklaşım olan ve geleneksel mücadele yöntemlerine oranla çok daha üstün özelliklere sahip nanoteknoloji uygulamalarının, fitopatolojik açıdan bazı kullanım olanakları sunulmuştur.

\section{Bitki Hastalıklarının Kontrolünde Nanopartiküller}

Son zamanlarda nanopestisitlerin bitki hastalıklarına etkileri denenmiş ve hastalıkların kontrolünde oldukça etkili bulunmuştur.

Tarımda kullanılan nanoformülasyonlar, kolaylıkla biyolojik olarak parçalanabilen, toksik olmayan, çevre dostu, güvenli ve düşük maliyetli materyallerin kullanımını gerektirmektedir. Bu yüzden çok iyi fiziksel ve kimyasal özellikleri olan doğal kaynakların biyopolimer üretiminde kullanımı, nanomateryal yapımında toksik 
kimyasal ve petrokimyasalların kullanımını önlemek için oldukça alternatif bir yaklaşımdır (Chowdappa ve Shivakumar, 2013).

Nanopartiküller hedef organizmalara karşı bazı etki mekanizmalarına sahiptir (Lemire ve ark., 2013). Bunlar; Kükürt içeren proteinlere bağlanabilen $\mathrm{Cd}^{+2}, \mathrm{Zn}^{+2}$ ve $\mathrm{Ag}^{+}$gibi toksik iyonların salınması ile membranlarda proteinlerin düzgün çalışmasını engellemek ve hücre geçirgenliğinde bozulmalara sebep olmak, genotoksik etkisiyle DNA'yı tahrip ederek hücre ölümlerine neden olmak, elektron taşınmasına negatif etkilerde bulunmak, reaktif oksijen türleri üretimi ile hücresel zararlanma oluşturmak ve besin alımını engellemek gibi mekanizmalardır (Zeng ve ark., 2007). Bu mekanizmalar tek başına çalışabildiği gibi bir ya da daha fazla mekanizma eş zamanlı olarak ta etki gösterebilmektedir.

Nanopartiküller genel olarak iki gruba ayrılmaktadır. Bunlardan birincisi karbon nanopartüküllerini içine alan organik nanopartiküller diğeri ise altın, gümüş, çinko oksit, titanyum oksit ve bakır gibi inorganik nanopartiküllerdir (Xu ve ark., 2006)

Kitosan nanopartikülleri toksik olmaması ve kolayca biyolojik olarak çözünebilme özelliğinden dolayı bazı tarımsal uygulamalarda başarılı bir şekilde kullanılabilmektedir. Asit ortamlarda kitosanın serbest amino grupları protonlanır ve pozitif yüküne katkıda bulunur (Paechamud ve Ritthidej, 2008). Kitosanın fungus gelişimini inhibe etme özelliği üç mekanizma sayesinde olmaktadır.

1. Kitosanın pozitif yükü fungus hücre duvarının negatif yüküyle etkileşime girer ve plazma membranının hücre geçirgenliğini değiştirerek hücre içeriğinin dışarıya sızmasına sebep olur ve bu sayede hücre ölümü gerçekleşir (Garcia Rincon ve ark., 2010).

2.Kitosan metal iyonlarıla birleşir (Rabea ve ark., 2003). İz elementlerine bağlandığı zaman fungusun temel besin elementleri alımını engelleyerek fungus gelişimini inhibe etmektedir (Roller ve Covill, 1999).

3.Kitosan, fungus hücre duvarına penetre olarak DNA'ya bağlanmakta ve mRNA sentezini durdurmaktadır. Bu sayede fungusun temel enzim ve proteinlerinin işleyişini bozmak suretiyle fungusun ölümüne sebep olmaktadır (Sudarshan ve ark., 1992; Kong ve ark., 2010).

Yapılan bazı çalışmaların sonucunda kitosan ve kitosan nanopartikülleri Fusarium solani gibi bitki patojenlerine karşı sentetik kimyasallara göre daha fazla başarı sağlamıştır. Kitosan nanopartiküllerinin engelleyici etkisi, partikül boyutları ve zeta potansiyeli tarafından ortaya çıkmaktadır. Bu sebepten dolayı kitosan doğal bir antifungal madde olarak başarılı bir şekilde tarımsal uygulamalarda kullanılmaktadır (Ing ve ark., 2012). Ortalama 117-965nm boyutlarında düşük molekül ağırıkı kitosan nanopartiküllerini kullanarak, kitosanın antibakteriyel etkisini çalışmışan Chen ve ark. (2010) kitosan nanopartiküllerinin bakteri hücre duvarının negatif yüküne bağlanmak suretiyle hücre duvarı zararlanmalarına yol açtığını, hücre içeriğini bozduğunu ve bunun sonucunda hücrelerin öldüğünü bildirmişlerdir.

Silikon bitkilerde hastalık ve stres direncini artırıcı bir özelliğe sahiptir (Brecht ve ark., 2004). Aynı zamanda bitki gelişimi ve fizyolojik aktiviteyi de teşvik etmektedir. Yapılan bir çalışmada DNA ve kimyasalları bitki hücrelerine aktarmak için $3 \mathrm{~nm}$ çapındaki balmumu-mezo gözenekli nanopartiküller (MSN) sistemini kullanmışlardır. MSN sistemine gen ve genin kimyasal indüktörünü yükleyerek uçlarını altın nanopartiküllerle kapatmak suretiyle kimyasalların serbest kalma modelini ve kontrollü salım şartları altında bitkideki gen expresyonunun indüklenmesini çalışmışlardır. Araştırıcılar, bu çalışma sonucunda protein, nükleotit ve kimyasalların hedefe özel olarak verilmesinde silica nanopartiküllerinin uygulanabilirliğini göstermişlerdir (Torney ve ark. 2007).

Çinko nanopartikülleri (ZnNPs) etkili bir fungisit olarak tarım ve gıda güvenliği uygulamalarında başarılı bir şekilde kullanılmaktadır. Çinko nanopartikülleri, hidroksil ve süperoksit radikallerinin yüksek enerjili transferi sayesinde fungal hücre duvarının deformasyonuna ve ölümüne sebep olmak suretiyle etkili olmaktadır (Patra ve Goswami, 2012). Hasat sonrasında da 
enfeksiyonlara neden olan Botrytis cinerea ve Penicillium expansum gibi fungal patojenlerin enfeksiyon oluşturmasını, $70 \mathrm{~nm}$ çaplı ZnO nanopartikülleri büyük oranda engellemektedir. $\mathrm{Bu}$ çalışmayla ZnO nanopartiküllerinin, fungus hiflerini deforme etmek suretiyle, konidi ve konidiofor gelişiminin engellenmesi ve bunun sonucunda ölüme sebep olmak suretiyle etkili olduğu ortaya koyulmuştur (He ve ark., 2011).

Gümüş geniş spektrumlu antimikrobiyal etkiye sahiptir. Fitopatojen türlerden, Fusarium culmorum (Kasprowicz ve ark., 2010), meşe solgunluk patojeni Rafflaelea sp. (Kim ve ark., 2009), Rhizoctonia solani, Sclerotinia sclerotiorum, Sclerotinia minor (Min ve ark., 2009), Bipolaris sorokiniana ve Magnaporthe grisea'nın (Jo ve ark., 2009) Ag nanopartiküllerine karşı duyarlı olduğu bildirilmiştir. Gümüş nanopartikülleri (AgNPs) Pseudomonas aeruginosa, Staphylococcus aureus, Aspergillus niger ve Aspergillus flavus'a karşı antimikrobiyal etkiye sahiptir. Gümüşün bu antimikrobiyal etkisi; fungal hücre duvarındaki sülfidril gruplarının ve hücrede lizize sebep olan membrana bağlı yağlar ile enzimlerin inaktivasyonunu sağlaması aracılığıyla gerçekleşmektedir (Govindaraju ve ark., 2010). AgNPs'nin antimikrobiyal etkisinin olduğu bir diğer mikroorganizma grubu da bakterilerdir. AgNPs hem gram (+) bakteriler olan Staphylococcus sp. ve Bacillus sp. hem de gram (-) bakteri $E$. coli üzerinde etkili olduğu bilinmektedir (Jaidev ve Narasimha, 2010). Morones ve ark.(2005) ise AgNPs nin E.coli bakterisinin hücre zarına bağlandığını ve burada lokalize olduğunu saptamışlardır. Aynı araştırıcı elektron mikroskobu kullanarak yaptığı araştırmada gümüş nanopartiküllerinin sadece hücre zarlarına tutunmadığını aynı zamanda bakteri hücrelerinin içlerine kadar girdiğini bildirmiştir. Gümüş nanopartikülleri bazı elementlerle reaksiyon vermeye oldukça meyillidir. E. coli bakterisinin hücre duvarına tutunan bu partiküller protonun itici gücüyle dağılma gösterirler ve bu sayede hücre duvarında geçirgenliğin de artmasıyla birlikte hücre içlerine girip hücrenin ölümüne sebep olmaktadırlar (Lok ve ark., 2006).
Çeşitli fitopatojen türleri kontrol etmede antimikrobiyal etkiye sahip (Jo ve ark., 2009; Kim ve ark., 2009; Min ve ark., 2009) gümüş partilüllerinin konukçu bitki üzerinde bazı olumsuz etkileri de rapor edilmiştir. AgNPs'nin kabakgil bitkilerinde tohum çimlenmesi ve kök gelişimine pozitif etkileri olmasına rağmen bu partiküllerin yetiştirme periyodu boyunca bitki biyokütlesi ve terleme üzerinde negatif etkileri olduğu ortaya koyulmuştur (Stampoulis ve ark. 2009). AgNPs'nin mikorizal funguslar üzerinde de etkileri bulunmaktadır. Kimyasal, biyolojik ve nanofungisitlerin mikorizal funguslarla kombineli kullanılarak etkilerinin karşılaştırıldığı bir çalışmada nanogümüş diğer fungisit gruplarına göre en yüksek etkiye sahip olmuştur (Abbasian ve ark. 2012).

Bakır kökenli fungisitler; yağlar, proteinler, DNA ve diğer biyomoleküllere zarar verebilen reaktif hidroksil üretmektedirler. Bu hidroksil gruplar birçok bitki hastalığının önlenmesinde ve tedavisinde kullanılmaktadır (Borkow ve Gabbay, 2005). Nanobakır (CuNPs) pirinç bakteriyel yanıklı̆ı (Xanthomonas oryzae pv. oryzae) ve fasulye adi yaprak yanıklığına (Xanthomonas campestris pv. phaseoli) sebep olan bakteriyel etmenlere karşı oldukça etkili bulunmuştur. Fakat CuNPs kullanılırken bazı önlemlerin alınması kuvvetle muhtemeldir. Çünkü Çevre Koruma Ajansı (EPA) nanobakırın mikrobakıra göre akut olarak on kat daha toksik olduğunu bildirmiştir. Çeşitli metal oksit nanopartiküller ve karbon nanotüplerin kıyaslandığı bir çalışmada, sitotoksisite ve DNA zararlanmalarına yol açan bütün nanopartiküller içinde en güçlü etkiye sahip olan ortalama $43 \mathrm{~nm}$ ile bakır oksit nanopartikülleridir (Gopal ve ark., 2011). Elektron mikroskop çalışmalarında, nanobakırın hücre membranından kolaylıkla geçebildiği görülmüştür. Nanobakırın bitki gelişimini de etkilediği yapılan çalışmalar sonucunda ortaya koyulmuştur. Kabakgil bitkilerinin gelişimi sırasında nano bakır partikülleri kök genişliğinin azalmasına sebep olmaktadır (Stampoulis ve ark., 2009). Marul bitkisinde ise tamamen farklı bir etki ile köklenme ve sürgün gelişimini arttırmıştır (Shah ve 
Belozerova, 2009).

Nanoteknolojik uygulamalar; tarım ürünlerinin kurutulması, depolanması ve muhafazası gibi hasat sonrası işlemlerde de başarıyla uygulanabilir durumdadır. Nanofilm ve nanokaplama yöntemleriyle mikroorganizma gelişimi kontrol altına alınabilmekte, ayrıca gaz ve zararlı ışınların etkisi engellenerek tarım ürünlerinin raf ömrü uzatılabilmektedir (Yadollahi ve ark.,2009). Meyvelerin kitosan/nanosilika hibrid filmi ile kaplanması sonucu raf ömrünün arttığı, yüzeysel kahverengileşmenin azaldığı, meyvede ağırlık kaybının geciktiği, meyvede malondialdehit ve polifenoloxidaz aktivitesinin artışının engellendiği bildirilmiştir (Shi ve ark. 2013).

Nanogümüşün gerbera bitkisinde hasat sonrasındaki etkilerinin araştırıldığı bir çalışmada, $5 \mathrm{mg} / \mathrm{L}$ oranındaki nanosolüsyonun vazo ömrünü uzattığı ve vazodan alınan sıvı örneğinde mikroskop incelemesi sonucunda bakteri gelişiminin inhibe edildiği gözlemlenmiştir (Liu ve ark. 2009). Ayrıca nanogümüşün hasat sonrasında bazı kesme çiçek türlerinin vazo ömrüne etkisi geniş bir şekilde araştırılmıştır. Bahsedilen bu nanopartikülün vazo ömrünü uzattığı ve bakterileri inhibe ettiği net birşekilde ortaya çıkmıştır (Kazemi veAmeri, 2012; Lü, ve ark.,2010; Li ve ark.,2012; Liu ve ark.,2012; Nazemi Rafi ve Ramezanian, 2013).

Fitopatolojik Açıdan Nanoteknolojinin Diğer Kullanım Alanları

Nanopartiküllerin ilgi çekici kullanım alanlarından biriside akıllı ya da hedefli ilaç salımına imkan sağlamasıdır (Banik ve Sharma, 2011). Nanopartiküllerin akıllı salım sistemlerinde kullanımı asırlar öncesinden Paul Ehrlich tarafından 'sihirli mermiler' olarak ifade edilmiştir(Himmelweit, 1960).

Bitkilerde akıllı salım- akıllı tedavi sistemlerini geliştirebilmek için Gonza'lez-Melendi ve ark. (2008) kabak bitkisini karbon kaplı demir nanopartikülleriyle muamele ederek bir çalışma yapmıştır. Demir partiküllerinin içerdiği manyetik çekirdekler organizmada manyetik alan oluşturmak suretiyle etkilenen bitki parçalarına kendilerinin taşınmasını sağlamıştır. Partiküllerde bulunan karbon bitkide biyouyumluluk sağlamakta ve çeşitli moleküllerin emilimi için bir yüzey alanı oluşturmak suretiyle görev yapmaktadır. $\mathrm{Bu}$ çalışmayla, araştırıcılar nanopartiküllerin bitki içine penetrasyonunu ve bitkide taşınabilirliğini bildirmiştir. Çalışmanın sonuçları nanopartiküllerin çeşitli bitki patojenleri için akıllı salımın potansiyelini ve uygulanabilirliğini göstermektedir (Banik ve Sharma, 2011).

Akıllı nanosalım sistemlerinin uzaktan etkinleştirilebilmesi ve izlenebilmesi pestisit kullanımını minimize etmektedir. Akıllı salım sistemleri nano ölçekteki kimyasalların olumsuz etkilerini ortadan kaldırmak için bir çözüm yolu olarak karşımıza çıkmaktadır. Akıllı salım sistemleri ile kendi kendini düzenleme özelliğine sahip olan bu nano ölçekteki partiküller hastalık ya da zararlı tarafından tahribat oluşturulan bitki dokularına gerekli miktarda ilacın transferini sağlamaktadırlar (Kamel ve Mousa,2015). Thiram ve Pyrimethanil gibi fungisitlerin akıllı salım sistemlerinde alginat, nişasta, kitosan, selüloz ve Hydroxypropyl- $\beta$-cyclodextrin gibi polisakkarit özelliğinde olan taşıyıcılar görev yapmaktadır. Thiram aktif maddeli fungisitler alginat, nişasta-kil patikülleri ve Agar-alginat partikülleri gibi taşıyıcı maddelere aktarılarak, pyrimethanil aktif maddeli fungisitler Hydroxypropyl $\beta$-cyclodextrinadlı taşıyıcıya aktarılarak akıllı salım sistemlerinde taşınmaktadır (Campos ve ark., 2015).

Nanosensörler küçük ve taşınabilir olup, fungal spor miktarı tespitinde güvenli ve stabil sonuçlar vermektedir. Bitki yetiştiriciliğinde enfeksiyonların saptanması önemli bir konudur. Nugaeva ve ark. (2005) tarafından geliştirilmiş bir sistemde Aspergillus niger ve Saccharomyces cerevisiae gibi fungusların sporlarının saptanmasında mikromekanik sistemler kullanılmıştır. Konkanavalin A, fibronektin veya immünoglobülin G gibi proteinler, altınla kaplanmış silikon taşıyıcı üzerine yüzeysel olarak aktarılmıştır. Bu proteinler fungal hücre yüzeyinde var olan moleküler yapılara bağlanma eğilimindedirler. Bu sistemler sayesinde fungal sporlar yakalanarak, dinamik 
olarak ölçümü ve kantitatif tahmini yapılmaktadır. Aynı zamanda bu nanosensörler yardımıyla fungus üzerinde $10^{3}-10^{6} \mathrm{cfu} \mathrm{ml}^{-1}$ oranında tespit edilmiştir (Banik ve Sharma, 2011).

Patojenlerin önceden ve doğru bir şekilde tespit edilmesi, bitkileri hastalıklardan korumak için pestisitlerin zamanında uygulanmasına yardımcı olmaktadır (Bergeson, 2010). Nanopartiküller, biyomarkör olarak veya fitobakterilerin (Boonham ve ark., 2008), virüslerin (Yao ve ark., 2009) ve fungusların saptanması için hızlı bir teşhis aracı olarak (Chartuprayoon ve ark., 2010) kullanılmasının yanısıra, hastalıklı bir durumu gösteren bileşikleri belirlemek için de kullanılabilmektedir.

Nanomateryal tabanlı nanosensörler, geleneksel gaz veya sıvı kromatografisi, kütle spektroskopisi tekniklerine alternatif olarak pestisit kalıntılarını tespit etmek amacıyla kullanılabilmektedir. Pestisit kalıntı analizlerinde kullanılan nanosensörler, yüksek hassasiyet, düşük konsantrasyon limitlerinin saptanması ve süper seçicilik sunmaktadır (Liu ve ark., 2008).

Nanoyapım teknikleri ksilem ve stoma gibi bitki kısımlarının yapay olarak sentezinde kullanılmaktadır. Sentezlenen bu bitki kısımları, Xylella fastidiosa, Colletotricum graminicola ve Uromyces apendiculatus gibi hastalık etmenlerinin konukçu bitkideki enfeksiyon süreci ve konukçudaki davranışlarını izlemek için halihazırda kullanılmaktadır (Meng ve ark., 2005). Bu yöntem sayesinde hastalığa dayanıklı bitkilerin geliştirilmesine olanak sağlanmaktadır.

\section{Sonuçlar}

Bitki patolojisinin de içinde bulunduğu yenilikçi araştırmalar için nanoteknoloji uygulamaları, biyoteknolojiden sonra ikinci bir devrim niteliğindedir. Birkaç yıl öncesine kadar tarımda nanoteknolojinin kullanımı çoğunlukla teorik olmuştur, fakat tarımsal kimyasal endüstrindeki nanoformülasyon gelişmeleriyle önemi hızla artmaya başlamıştır (Thul ve Sarangi 2015). Geleneksel pestisitlere göre daha etkili mekanizmalara sahip olması, yapısındaki çok az miktarda bulunan aktif madde ile diğerlerine oranla daha az risk oluşturması ve aktif maddenin kontrollü bir şekilde salınımına olanak sağlamasıyla nanopestisitler, etkin hastalık kontrolü sağlanmaktadır.

Ayrıca fitopatolojik açıdan nanoteknolojinin diğer kullanım alanlarında bahsedildiği gibi nanoyapım teknikleri aracılığıyla patojenlerin bitki içerisindeki hareket yeteneklerinin izlenebilirliği ile dayanıklı çeşit geliştirme açısından da ilerlemeler kaydedilmiştir. Bu özellikleri göz önünde bulundurulduğu zaman hastalıklarla mücadelede nanoteknolojinin kullanımı ve uygulanabilirliği oldukça dikkat çekicidir.

Ülkemizdeki durumu fitopatolojik açıdan değerlendirildiğinde, gelişiminin ilk aşamalarında olan nanoteknolojinin, multidisipliner çalışmalarla geliştirilmesi ve kolaylıkla pratiğe aktarılabilmesi büyük önem taşımaktadır.

\section{Kaynaklar}

Abbasian, M., Kashani, A., Ardakani, M.R., Rejali, F., Timajchi, M., Seifi, S.M., Mafakheri, S., 2012. The Effects of Chemical, Biological and Nano Fungicides on Mycorrhizal Colonization and Quality of Sunflower. Annals of Biological Research, 3 (8): 42394245.

Banik, S., Sharma, P., 2011. Plant pathology in the era of nanotechnology. Indian Phytopathology, 64(2): 120127.

Bergeson, L.L., 2010. Nanosilver pesticide products: What does the future hold? Environ. Qual. Manage, 19: 7382.

Boonham, N., R. Glover, J. Tomlinson and R. Mumford, 2008. Exploiting generic platform technologies for the detection and identification of plant pathogens. Eur. J. Plant Pathol., 121: 355-363.

Borkow, G., Gabbay, J., 2005. Copper as a biocidal tool. Current Medicinal Chemistry, 12(18): 2163-2175.

Brecht, M.O., Datnoff, L.E., Kucharek, T.A., Nagata, R.T., 2004. Influence of silicon and chlorothalonil on the suppression of gray leaf spot and increase plant growth in St. Augustinegrass. Plant Disease, 88(4): 338-344.

Campos E.V.R., Oliveira J..LD., Fraceto LF., Baljit Singh B., 2015. Polysaccharides as safer release systems for agrochemicals. Agron. Sustain., Dev, 35(1): 47-66.

Chartuprayoon, N., Y. Rheem, W. Chen, N., Myung, 2010. Detection of plant pathogen using LPNE grown single conducting polymer Nanoribbon. Proceedings of the 218th ECS Meeting, October 10-15, 2010, Las Vegas, Nevada, pp: 2278-2278.

Chen, L.C., Kung, S.K., Chen, H.H., Lin, S.B., 2010. Evaluation of zeta potential difference as an indicator for 
antibacterial strength of low molecular weight chitosan. Carbohydrate Polymers, 82(1): 913-919.

Chowdappa, P., Shivakumar, G., 2013. Nanotechnology in crop protection: Status and scope. Pest Management in Horticultural Ecosystems, 19(2): 131-151.

Çıracı, S., 2005. Metrenin Bir Milyarda Birinde Bilim ve Teknoloji, Bilim ve Teknik, Ağustos, Ek sayı: 6-10.

Dubchak, S., Ogar, A., Mietelski, J.W., and Turnau, K., 2010. Influence of silver and titanium nanoparticles on arbuscular mycorrhiza colonization and accumulation of radiocaesium in Helianthus annuus. Spanish J. Agric. Res., 8: 103-108.

Garcia Rincon, J., Vega Perez, J., Guerra Sinchez, M.G., Hernndez Lauzardo, A.N., Peqa Diaz, A., Velizquez Del Valle, M.G., 2010. Effect of chitosan on growth and plasma membrane properties of Rhizopus stolonifer (Ehrenb.:Fr.) Vuill. Pesticide Biochemistry and Physiology, 97(3): 275-278.

González Melendi, P., Fernández Pacheco, R., Coronado, M.J., Corredor, E., Testillano, P.S., Risueño, M.C., Marquina, C., Ibarra, M.R., Rubiales, D., Pérez de Luque, A., 2008. Nanoparticles as Smart Treatment delivery Systems in Plants: Assessment of Different Techniques of Microscopy for their Visualization in Plant Tissues. Annals of Botany, 101(1): 187-195.

Gopal, M., Gogoi, R., Srivastava, C., Kumar, R., Singh, P., Nair, K., Yadav, S., Arunava Goswamı, A., 2011. Nanotechnology and its application in plant protection. Plant Pathology in India: Vision 2030, Indian Pathology Society, India 224-232pp.

Govindaraju, K., Tamilselvan, S., Kiruthiga, V., Singaravelu, G., 2010. Biogenic silver nanoparticles by Solanum torvum and their promising antimicrobial activity. Journal of Biopesticides, 3(1): 394-399.

He, L., Liu, Y., Mustapha, A., Lin, M., 2011. Antifungal activity of zinc oxide nanoparticles against Botrytis cinerea and Penicillium expansum. Microbiological Research, 166(3): 207-215.

Himmelweit, F., 1960. The collected papers of Paul Ehrlich, Vol. 3. London: Pergamon Press.615 pp.

Ing, L.Y., Zin, N.M., Sarwar, A., Katas, H., 2012. Antifungal activity of chitosan nanoparticles and correlation with their physical properties. International Journal of Biomaterials, 2012: 1-9.

Jaidev, L.R., Narasimha, G., 2010. Fungal mediated biosynthesis of silver nanoparticles, characterization and antimicrobial activity. Colloids surf. $B$, Biointerfaces, 81(2): 430-433.

Jo, Y.K., Kim, B.H., Jung, G., 2009. Antifungal activity of silver ions and nanoparticles on phytopathogenic fungi. Plant Disease, 93(10): 1037-1043.

Kamel, A., Mousa, A., 2015 Nanobiofungicides: are they the Next-Generation of Fungicides? Journal of Nanotechnology and Materials Science, 2(1): 1-3.

Kasprowicz, M.J., Koziol, M., Gorczyca, A., 2010. The effect of silver nanoparticles on phytopthogenic species of Fusarium culmorum. Journal of Microbiology, 56(3): 247-253.

Kazemi, M., Ameri, A., 2012. Postharvest life of cut gerbera flowers as affected by nano-silver and acetylsalicylic acid. Asian Journal of Biochemistry, 7(2): 106-111.

Khan, M.R and Rizvi, T.F., 2014. Nanotechnology: Scope and application in plant disease management. Plant
Pathology Journal, 13(3): 214-231.

Khan, M.R., Haque, Z., Kausar, N., 2014. Management of the root-knot nematode Meloidogyne graminicola infesting rice in the nursery and crop field by integrating seed priming and soil application treatments of pesticides. Crop Protection, 63: 15-25.

Kim, S.W., Kim, K.S., Lamsal, K., Kim, Y.J., Kim, S.B., Jung, M., Sim, S.J., Kim, H.S., Chang, S.J., Kim, J.K., Lee, Y.S., 2009. An in vitro study of the antifungal effect of silver nanoparticles on oak wilt pathogen Raffaelea sp. Journal of Microbiology and Biotechnology, 19(8): 760- 764.

Kong, M., Chen, X.G., Xing, K., Park, H.J., 2010. Antimicrobial properties of chitosan and mode of action: a state of the art review. International Journal of Food Microbiology, 144(1): 51-63.

Koul, O., Walia, S., Dhaliwal, G.S., 2008. Essential oils as green pesticides: potential and constraints. Biopestic Int, 4(1): 63-84.

Lemire, J.A., Harrison, J.J., Turner, R.J., 2013. Antimicrobial activity of metals: mechanisms, molecular targets and applications. Nat Rev Microbiol, 11(6):371-384.

Li, H., Huang, X., Li, J., Liu, J., Joyce, D., He, S., 2012. Efficacy of nano-silver in alleviating bacteria-related blockage in cut rose cv. Movie Star stems. Postharvest Biology and Technology, 74: 36-41.

Liu, S., Yuan, L., Yue, X., Zheng, Z., and Tang, Z., 2008. Recent advances in nanosensors for organophosphate pesticide detection. Adv. Powder Technol., 19: 419-441.

Liu, J., He, S., Zhang, Z., Cao, J., Lv, P., He, S., Cheng, G., Joyce, D.C., 2009. Nano-silver pulse treatments inhibit stem-end bacteria on cut gerbera cv. Ruikou flowers. Postharvest Biology and Technology, 54: 5962.

Liu, J., Ratnayake, K., Joyce, DC., He, S., Zhang, Z., 2012. Effects of three different nano-silver formulations on cut Acacia holosericea vase life. Postharvest Biology and Technology, 66: 8-15.

Lok, CN., Ho, C.M., Chen, R., He, Q.Y., Yu, W.Y., Sun, H., Tam, P.K., Chiu, J.F. Che, C.M., 2006. Proteomic analysis of the mode of antibacterial action of silver nanoparticles. Journal of Proteome Res., 5(4): 916924.

Lü, P., Cao, J., He, S., Liu, J., Li, H., Cheng, G., Ding, Y., Joyce, D.C., 2010. Nano-silver pulse treatments improve water relations of cut rose cv. Movie Star flowers. Postharvest Biology and Technology, 57: 196-202.

Meng, Y., Li, Y., Galvani, C.D., Hao, G., Turner, J.N., Burr, T.J., Hoch, H.C., 2005. Upstream Migration of Xylella fastidiosa via Pilus-Driven Twitching Motility. Journal of Bacteriology, 187(16): 5560-5567.

Min, J.S., Kim, K.S., Kim, S.W., Jung, J.H., Lamsal, K., Kim, S.B., 2009. Effects of colloidal silver nanoparticles on sclerotium forming phytopathogenic fungi. Journal of Plant Pathology, 25(4): 376-380.

Morones, J.R., Elechiguerra, J.L., Camacho, A., Holt, K., Kouri, J.B., Ramírez, J.T., Yacaman M.J., 2005. The bactericidal effect of silver nanoparticles. Nanotechnology, 16(10): 2346-2353.

Nazemi Rafi, Z., and Ramezanian, A., 2013. Vase life of cut rose cultivars Avalanchei and Fiestai as affected by NanoSilver and S-carvone treatments. South African 
Journal of Botany, 86: 68-72.

Nugaeva, N., Gfeller. K.Y., Backmann, N., Lang, H.P., Duggelin, M. and Hegner, M., 2005. Micromechanical cantilever array sensors for selective fungal immobilization and fast growth detection. Biosensors and Bioelectronics, 21(6): 849-856.

Phaechamud, T., Ritthidej, G.C., 2008. Formulation variables influencing drug release from layered matrix system comprising chitosan and xanthan gum. AAPS Pharm SciTech, 9(3): 870-877.

Patra, P., Goswami, A., 2012. Zinc nitrate derived nano ZnO: Fungicide for diseas e management of horticultural crops. International Journal of Innovative Horticulture, 1(1):28-33.

Rabea, E.I., Badawy, M.E.T., Stevens, C.V., Smagghe, G., Steurbaut, W., 2003. Chitosan as Antimicrobial Agent: Applications and Mode of Action. Biomacromolecules, 4(6): 1457-1465.

Roller, S., Covill, N., 1999. The antifungal properties of chitosan in laboratory media and apple juice. International Journal of Food Microbiology, 47(1-2): 67-77.

Shah, V., Belozerova, I., 2009. Influence of metal nanoparticles on the soil microbial community and germination of lettuce seeds. Water Air Soil Pollution, 197: 143-148.

Sharon, M., Choudhary, A.K., Kumar, R., 2010. Nanotechnology in agricultural diseases and food safety. Journal of Phytology, 2(4), 83-92.

Shi, S., Wang, W., Liu, L., Wu, S., Wei, Y., Li, W., 2013. Effect of chitosan/nano-silica coating on the physicochemical characteristics of longan fruit under ambient temperature. Journal of Food Engineering, 118(1): 125-131.

Singh, J., 2006. Nanomaterials and Nanotechnology. Asian Journal of Chemistry, 18(5): 3271-3274.

Stampoulis, D., Sinha, S.K., White, J.C., 2009. Assay- dependent phytotoxicity of nanoparticles to plants. Environment Science. Technolog, 43(24): 9473-9479.

Sudarshan, N.R., Hoover, D.G., Knorr, D., 1992. Antibacterial action of chitosan. Food Biotechnology, 6(3): 257272.

Tegart, G., 2003. Nanotechnology: The Technology for the 21th Century. The Second International Conference on Technology Foresight, 27-28 Şubat, 1-12s. Tokyo.

Torney, F., Trewyn, B.G., Lin, V.S.Y., Wang, K., 2007. Mesoporous silica nanoparticles deliver DNA and chemicals into plants. Nature Nanotechnology, 2(5): 295-300.

Thul, S.T., and Sarangi, B.K., 2015. Implications of Nanotechnology on Plant Productivity and Its Rhizospheric Environment. Nanotechnology and Plant Sciences.

Vijayalakshmi, C., Chellaram C., Kumar S.L., 2015. Modern Approaches of Nanotechnology in Agriculture-A Review. Bioscience Biotechnology Research Asia, 12(1): 327-331.

Yadollahi, A., Arzani, K.,Khoshghalb, H., 2009. The Role of Nanotechnology in Horticultural Crops Postharvest Management. Southeast Asia Symposium on Quality and Safety of Fresh and Fresh-Cut Produce, 3-5 August, 49-56p. Bangkok.

Yao, K.S., Li, S.J., Tzeng, K.C., Cheng, T.C. and Chang, C.Y. 2009. Fluorescence silica nanoprobe as a biomarker for rapid detection of plant pathogens. Adv. Mater. Res., 79-82: 513-516.

Zeng, F., Hou, C., Wu, S.Z., Liu, X.X., Tong, Z., Yu, S.N., 2007. Silver nanoparticles directly formed on natural macroporous matrix and their anti-microbial activities. Nanotechnology, 18:1-8.

Xu, Z.P., Zeng, Q.P., Lu, G.Q and Yu, A.B 2006. Inorganic nanoparticles as carriers for efficient cellular delivery. Chemical Engineering Science, 61: 10271040. 